\title{
Racial and Ethnic Differences in Ocular Anatomy
}

\section{Richard Blake, M.D.}

Wico W. Lai, M.D.

Deepak P. Edward, M.D., FACS

Understanding anatomical structure, proportion, and mechanical function of the human body is vital to clinical assessment and treatment of patients. Ethnic variations in ocular anatomy and in the prevalence and severity of eye diseases are well recognized. In this chapter, we review such ophthalmic differences between various racial and ethnic groups.

\section{- Eyelids}

Differences in eyelid structure are well described in the literature with respect to the Asian eyelid, but discussion of differences in eyelid structure between the other races is scarce. Most of the literature focuses on distinctions between "double" and "single" eyelids. Other clinical and surgical considerations are the presence of epicanthi and palpebral fissure slant. By understanding racial and ethnic anatomical differences, oculoplastic surgeons will be able to optimize function and aesthetics. ${ }^{1}$

Asians may have fuller, thicker-appearing upper eyelids with an absent or relatively lower upper lid (supratarsal) fold, making the distinction between the single and double eyelid (Figs 1, 2) ${ }^{2-6}$ The orbital septum of Asians fuses with the levator palpebrae aponeurosis at variable distances below the superior tarsal border, closer to the eyelid margin than in non-Asians. This hinders aponeurotic fibers from the levator palpebrae superioris from reaching the subcutaneous tissues, prohibiting the creating of a double eyelid crease. ${ }^{5,6}$ The fusion is above the superior tarsal

The authors have no proprietary interest. 


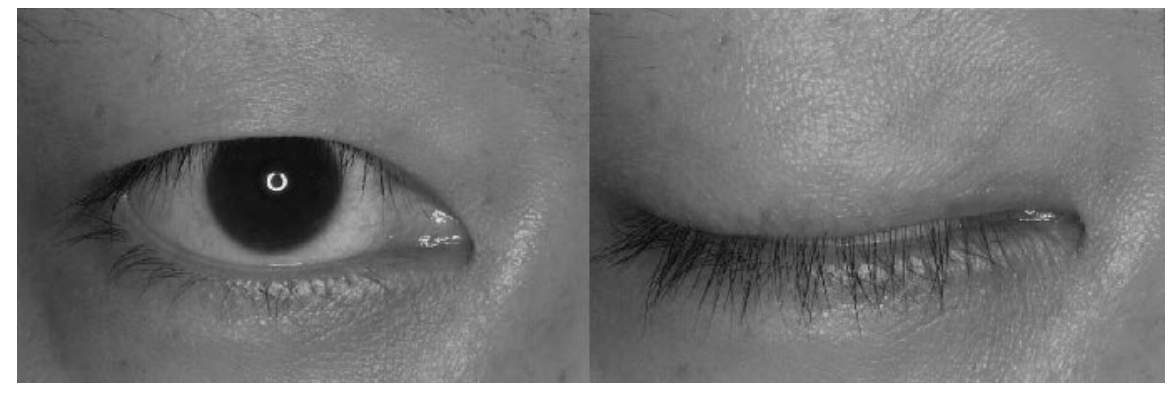

Figure 1. Asian eyelid showing absence of upper lid fold and the appearance of a "single" eyelid. Note the presence of epicanthus.

border in whites, creating the appearance of a double eyelid crease. Asian eyelids show a double or single crease, depending on how far inferior the levator palpebrae superioris inserts on the tarsus.

On the basis of gross, histological, and radiographic studies, a double creased eyelid is created by fibers of the levator palpebrae superioris penetrating the orbicularis oculi muscle and then inserting into the subcutaneous tissue of lid. More anterior coverage by adipose tissue of the tarsal margin of the upper eyelid can occur without the anchoring of the upper eyelid skin. ${ }^{3,5,6}$ In one study, Asian double eyelid creases showed an amount of pretarsal fat intermediate between Asian single eyelids and whites' eyelids. ${ }^{6}$

A study by Carter and associates ${ }^{7}$ comparing Asian and white lower lid anatomy with magnetic resonance imaging revealed two major differences. First, all Asian lower lids studied showed orbital fat protruding farther anterior relative to the orbital rim as compared to that of whites. Second, in those Asian lower eyelids that did not have well-defined creases, the orbital fat extended further superiorly, to the inferior border of the tarsus. The researchers did not find any differences in the suborbicularis oculi fat pad in the lower lid between the two races. They con-

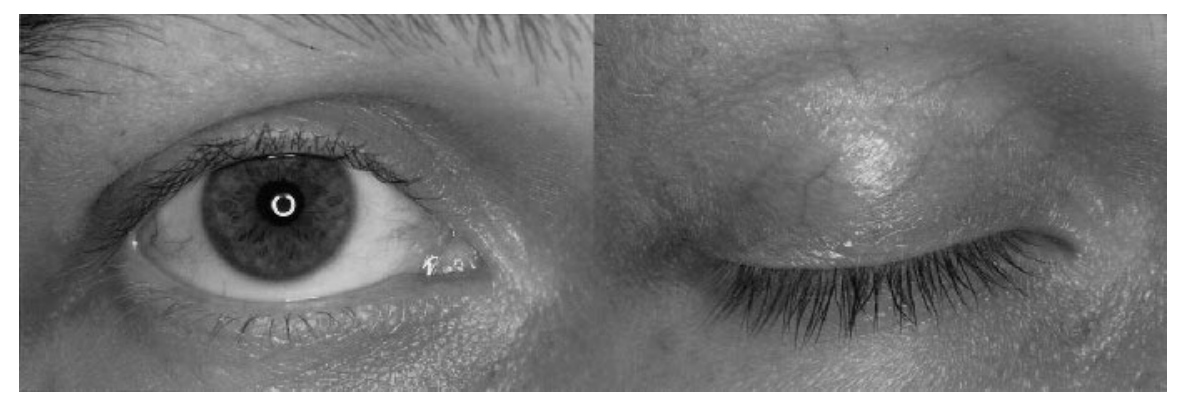

Figure 2. Caucasian eye with a "double" eyelid crease. 
cluded that the Asian lower lid appearance is explained by differences in orbital fat location.

Epicanthi are folds of skin in the inner canthal area. The condition is more common in Asians, and the fold of skin often hides the caruncle. ${ }^{3}$ Minor epicanthi were defined as fine, short folds of skin not crossing the level of the inner commissure. Major epicanthi were defined as those epicanthi blocking the view of the inner commissure. ${ }^{8}$ In one study, minor epicanthi were found to be more common than major epicanthi in white children. No significant differences in standard orbital measurements between those with minor epicanthi and those without epicanthi were found, which indicates that minor epicanthi are a variant of normal anatomy. It has been proposed that with the growth of a smaller-thanaverage nasal root and brow, a major epicanthus may disappear as a child grows. ${ }^{3,8}$ The presence of major epicanthi in white children appears to be a less common variant of normal. ${ }^{8}$ However, the persistence of major canthi into adulthood can be associated with skeletal hypoplasia, lid defects, or stigma of other diseases. ${ }^{9}$

A recent and unique study by Hanada and coinvestigators ${ }^{10}$ compared the obliquity of the palpebral fissures between Brazilian indigenous peoples, Brazilian whites, and Brazilian Japanese. The mean fissure angles were measured as 9.39 degrees for Japanese, 9.64 for those in the indigenous group, and 4.60 for the whites. Statistical difference was found only between whites and the other two groups. Further study among races may be warranted.

\section{- Orbit}

Racial and ethnic anatomical differences regarding globe and orbit position are of special importance in examining patients who have experienced head trauma or may have possible autoimmune, neoplastic, and infectious or congenital diseases. Exophthalmometry measuring the amount of protrusion of the globe from the bony orbit is usually obtained by the Hertel exophthalmometer. Normative data for both black and white populations have been published, and the data correlate well among different studies (Table 1). ${ }^{11-13}$ In general, globe protrusion in blacks tends to be at the upper limit of normal for what has been reported for whites (Figs 3, 4). Data for other races have not been well documented. Normal Mexican adults (301 subjects) showed a mean Hertel exophthalmometry measurement of $15.18 \pm 2.16 \mathrm{~mm}$ for males and $14.82 \pm 1.98$ for females, which tends to be lower than that of blacks and whites in the United States. ${ }^{14}$ Further studies comparing these groups in the same study are warranted to determine whether there is a difference between these groups.

Intercanthal and interpupillary distances also are important measure- 
Table 1. Protrusion of the Globe $(\mathrm{mm})$

\begin{tabular}{|c|c|c|c|c|}
\hline \multirow[b]{2}{*}{ Study } & \multicolumn{2}{|c|}{ Whites } & \multicolumn{2}{|c|}{ Blacks } \\
\hline & Means $\pm \mathrm{SD}$ & Ranges & Means \pm SD & Ranges \\
\hline \multicolumn{5}{|c|}{ Migliori and Gladstone ${ }^{11}$} \\
\hline Male, $p<.025$ & $16.5 \pm 2.58$ & $11.3-21.7$ & $18.5 \pm 3.08$ & $12.3-24.7$ \\
\hline Female, $p<.025$ & $15.4 \pm 2.33$ & $10.7-20.8$ & $17.8 \pm 2.57$ & $12.6-23.0$ \\
\hline \multicolumn{5}{|l|}{ Dunsky $^{12}$} \\
\hline Male & - & - & $18.2 \pm 2.97$ & $12.3-24.1$ \\
\hline Female & - & - & $17.5 \pm 2.64$ & $12.2-22.7$ \\
\hline \multicolumn{5}{|c|}{ Barretto and Mathog ${ }^{13}$} \\
\hline Male, $p<.025$ & $17.0 \pm 2.65$ & $11.7-22.3$ & $18.23 \pm 2.26$ & $13.7-22.8$ \\
\hline Female, $p<.01$ & $15.98 \pm 2.22$ & $11.5-20.4$ & $17.27 \pm 1.44$ & $14.4-20.2$ \\
\hline
\end{tabular}

ments in evaluating congenital and posttraumatic deformities. Pryor ${ }^{15}$ reported normal values of inner canthal distance (ICD), outer canthal distance (OCD), and interpupillary distance (IPD) for young (birth to 15 years old) white, Asian-, and Mexican-Americans. Pivnick and associates ${ }^{16}$ reported these values for blacks (birth to 24 years old) and compared them to Pryor's previous study. The values of IPD and OCD in blacks reported by Pivnick and associates ${ }^{16}$ were practically all significantly higher than those of age- and gender-matched white counterparts in Pryor's study. Interestingly, the former reported that blacks had a significantly smaller ICD at birth than did whites and that the ICD tended to grow at a more rapid rate than that of whites during the first 3 months of

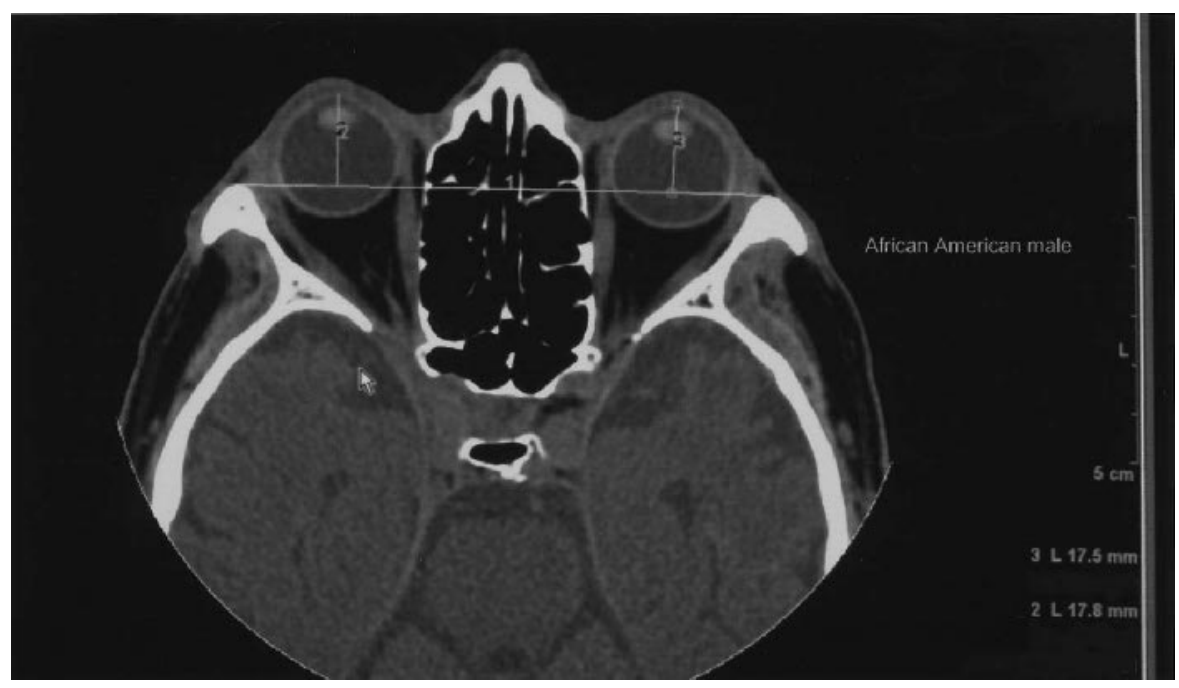

Figure 3. Computed tomography of the orbits of an African-American patient. The vertical lines represent the distance between the cornea and the lateral orbital rim. 


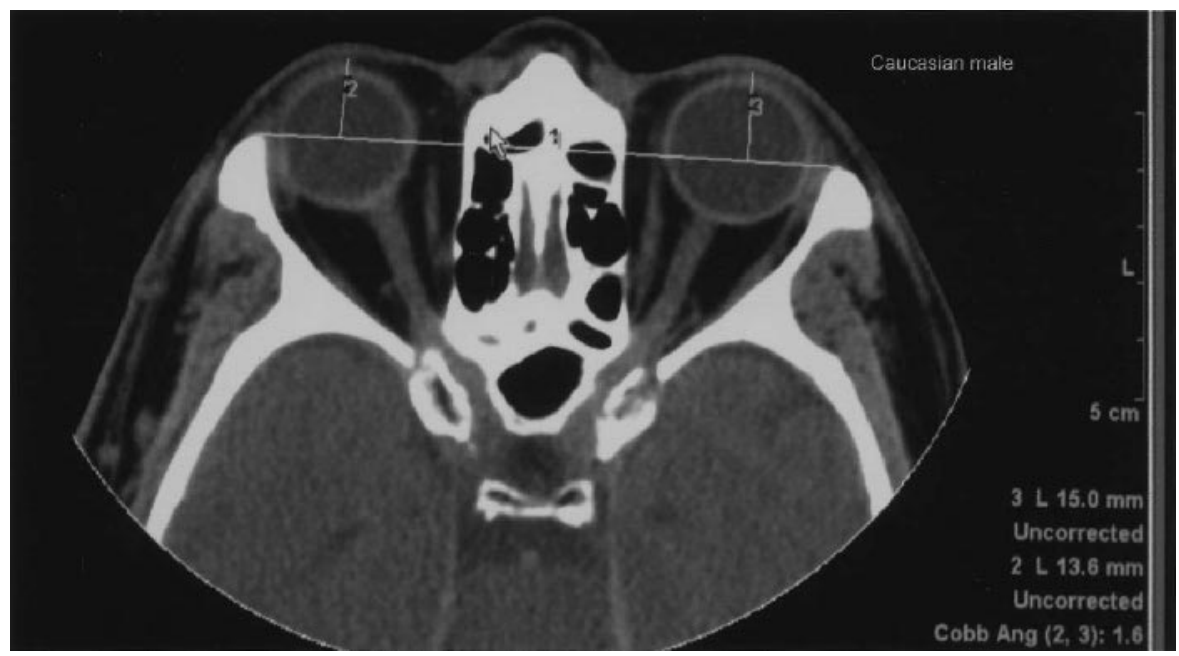

Figure 4. Computed tomography of the orbits of a white patient. Note that the cornea-lateral orbital rim distance is higher in African-American patients than that in white patients.

life. After 9 months of age, the mean ICD remained significantly larger in blacks than in whites. Therefore, our clinical orbital measurements should be assessed not only for age but also for race. Highly detailed tables correlating age, race and measurements are published in the foregoing articles. ${ }^{15,16}$

In contrast to the study by Pivnick and associates, Barretto and Mathog ${ }^{13}$ did not find any statistically significant difference between the ICD in normal black and white adults. Furthermore, they did not find any statistical difference in the palpebral fissure height between blacks and whites. However, in agreement with other studies, ${ }^{11,12,16}$ they did demonstrate a statistically larger difference in blacks than whites in regard to global projection and interpupillary distance. A statistical difference was also found between the races with respect to palpebral fissure width. The values of different measurements between blacks and whites reported in the study by Barretto and Mathog are in Table 2.

One study compared external orbital measurements (using projective photographs) of Arab men to other ethnic groups (using measurements obtained from other studies). ${ }^{17}$ Men of Arab descent had an OCD similar to that of whites but smaller than that of Japanese. The ICDs measured in Arabs were on average larger than those of whites. Both African-Americans and Japanese had wider IPDs than those of Arab descent in the study.

\section{- Refractive Error}

The ocular components that are innately responsible for ethnic differences in refractive error include axial length (AL), lens power, and 


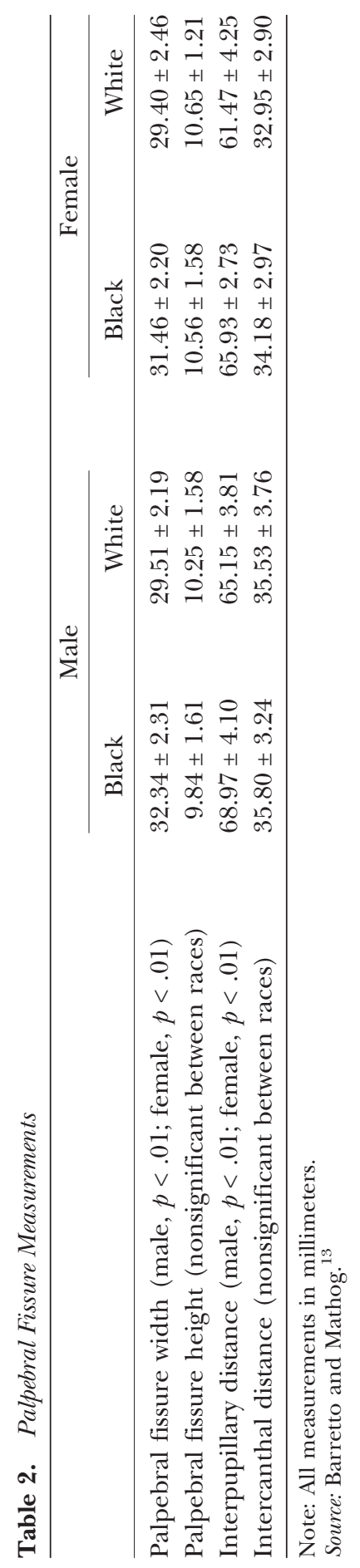

14

Copyright @ Lippincott Williams \& Wilkins. Unauthorized reproduction of this article is prohibited. 
corneal curvature. Even though AL has been thought of traditionally as having the greatest impact on amount of myopia, rigorous ocular component measurements in samples that deal with ethnic variation have been infrequent. There have been studies that have directly correlated the degree of myopia with increasing AL. ${ }^{18}$ Lam and $\mathrm{Goh}^{18}$ demonstrated that the presence of myopia in Asian and white school children correlates well to their longer AL. However, Chinese subjects in a study by Congdon and colleagues ${ }^{19}$ were noted to have significantly smaller radii of corneal curvature and less hyperopia than blacks or whites, without significant differences in their AL. Again, to the contrary, a recent biometric comparative study found that Inuits tended on average to be more hyperopic and have flatter radii of corneal curvatures but also tended to have longer ALs than did blacks, Chinese, and whites. ${ }^{20}$

There have been sporadic studies on ethnic prevalence of refractive errors. ${ }^{21-25}$ This is due to the fact that it is a monumental task to compare data between races, owing to confounding factors that may affect the prevalence of myopia, such as education, geographical area, and different socioeconomic and educational status. Sperduto and associates ${ }^{21}$ performed a thorough study of the refractive data $(9,882$ patients) in the 1971 National Health and Nutrition Examination Survey and estimated the prevalence of myopia in the United States for blacks (13\%) and whites $(26 \%)$. They found that white subjects had a substantially higher prevalence of myopia than did blacks on average $(p<.01)$, with whites having higher rates of myopia at all age groups studied.

Two very large studies on Singaporean subjects have reported that Chinese subjects have more myopia than do Indians and Malays. Au Eong and associates ${ }^{22}$ estimated the prevalence of myopia in 110,236 Singaporean subjects to be $48.5 \%$ in Chinese, $34.7 \%$ in Eurasians, $30.4 \%$ in Indians, and $24.5 \%$ in Malays. After matching the groups for educational attainment, differences in the prevalence of myopia were still seen. $\mathrm{Wu}^{23}$ and associates found a significant ethnic difference of the prevalence of myopia in Chinese, Indians, and Malays $(p=.01)$. The mean refractive errors were $-2.75 \mathrm{D},-1.13 \mathrm{D}$, and $-0.88 \mathrm{D}$, respectively. The prevalence of myopia was strongly associated with years of education. Again, after adjusting for education, those in the Chinese group still differed significantly from the other two groups $(p<.001)$.

Since the 1930s, a high rate of myopia has been noticed in Far East Asia. ${ }^{26}$ Studies of the prevalence of myopia consistently indicate that myopia is more prevalent in those of Asian descent than in whites and blacks. Table 3 summarizes the studies.

\section{- Conjunctiva and Sclera}

Knowing racial differences of conjunctival, episcleral, and scleral pigmentation is of clinical value, especially with regard to the premalignant 
Table 3. Prevalence of Myopia

\begin{tabular}{|c|c|c|c|}
\hline Study & Race & $\begin{array}{l}\text { Age } \\
\text { (Yr) }\end{array}$ & $\begin{array}{c}\text { Prevalence } \\
(\%)\end{array}$ \\
\hline \multirow[t]{2}{*}{ Zadnik et al. ${ }^{24}$} & Asian & $6-14$ & 27.3 \\
\hline & Caucasian & $6-14$ & 8.8 \\
\hline \multirow[t]{2}{*}{ Sperduto et al. ${ }^{21}$} & African-American & $12-54$ & 13.0 \\
\hline & Caucasian & $12-54$ & 26.3 \\
\hline Beaver Dam Eye Study ${ }^{25}$ & Caucasian & $48-84$ & 26.2 \\
\hline Lam and Goh ${ }^{18}$ (Hong Kong Schools) & Asian & $6-17$ & 55.0 \\
\hline
\end{tabular}

and malignant lesions that occur in these tissues. In general, darkerskinned races tend to have more ocular pigmentation. ${ }^{27}$ This racial pigmentation in conjunctiva imparts a brownish color to tissue, while pigment deeper in the sclera or episclera gives more of a gray or bluish hue. Three normal types of external ocular melanotic pigmentation are conjunctival epithelial melanosis, episcleral melanosis, and intrascleral nerve loop pigmentation, all of which are first noticeable from birth or early childhood. ${ }^{27}$

Conjunctival epithelial melanosis occurs mainly on the bulbar conjunctiva and appears patchy, flat, and brownish. The limbus and palpebral conjunctiva may be involved, and the pigmentation may be extended into the corneal epithelium. Conjunctival epithelial melanosis should be freely moveable over the sclera, occurring less frequently at the limbus and caruncle in whites. ${ }^{27}$ It should be differentiated from premalignant or malignant pigmented conjunctival lesions that are mainly seen in whites.

Episcleral melanosis, a common racial characteristic in blacks and Asians, appears as pigmented spots that are bilateral and brown or grayblue in color. Episcleral melanosis occurs more often in individuals with dark irides. In whites, episcleral melanosis is associated with an increased risk of melanosis oculi and therefore an increased risk of a uveal melanoma. ${ }^{27}$

Intrascleral nerve loops and associated scleral emissaries are pigmented more often in darker-skinned races (Fig 5). ${ }^{28,29}$ In two studies, ${ }^{28,29}$ the emissary pigmentation seemed to be independent of ultraviolet light exposure as most of the pigmented scleral emissaries occurred under the upper lid and least frequently lateral, where there would be more ultraviolet exposure. Norn ${ }^{28}$ found that episcleral pigment spots bearing relation to scleral canal emissaries were more frequent among Inuits (85\% total prevalence), less among Japanese (68\%), and least among the Northern Europeans (16\%). A histological study performed by Yanoff $^{29}$ found that the episcleral spots $(0.1-0.5 \mathrm{~mm}$ in diameter) were composed of uveal melanocytes always associated with a perforating anterior ciliary vessel or intrascleral nerve root or both. All eyes of black subjects had some pigmented emissaries and, in the eyes from both 
Figure 5. External photograph of an African-American patient showing intrascleral nerve loop and associated scleral emissary.

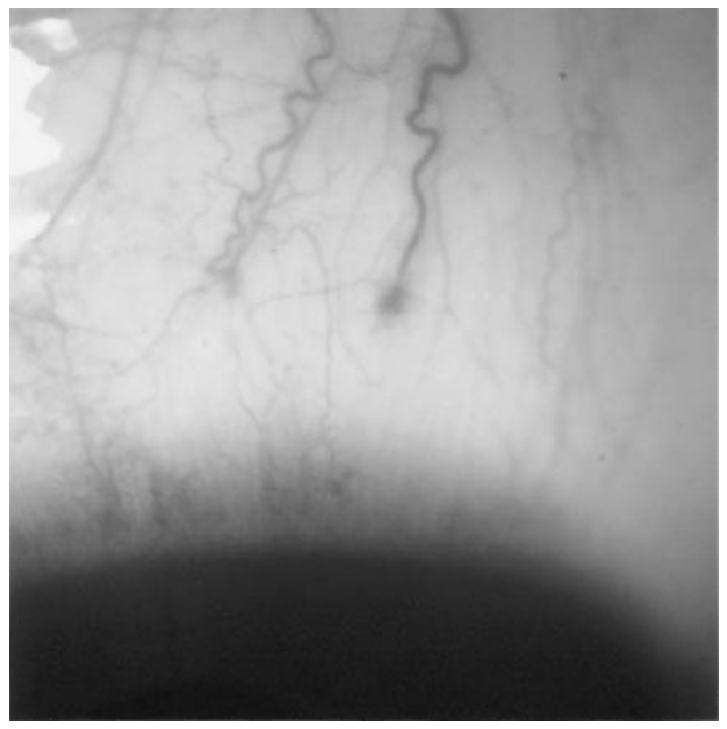

groups, pigmented emissaries were found on average 3 to $4 \mathrm{~mm}$ (range, 1-7 mm) from the limbus. They tended to occur most commonly superiorly then temporally, nasally, and inferiorly (in decreasing frequency).

\section{- Cornea}

Corneal thickness measurement is becoming increasingly important in diagnosing and treating certain corneal diseases and in the workup of glaucoma and ocular hypertension. African-Americans on average have thinner central corneal thickness (CCT) as compared with white Americans. $^{30,31}$ Those with thin corneas have higher intraocular pressures than that measured by applanation tonometry. This was addressed in the Ocular Hypertension Treatment Study. ${ }^{30}$ In this study, the mean $( \pm \mathrm{SD})$ corneal thickness of African-American subjects $(555.7 \pm 40.0 \mu \mathrm{m})$ was $23 \mu \mathrm{m}$ thinner than that of whites $(579.0 \pm 37.0 \mu \mathrm{m})$. In a previous, smaller study, La Rosa and associates ${ }^{31}$ also found with distribution analysis that the largest cluster of African-American patients had CCT around 520 to 540 $\mu \mathrm{m}$, whereas the largest cluster of white patients had CCT around 580 to $600 \mu \mathrm{m}$.

The CCTs (mean \pm SD) in Japanese and Hong Kong Chinese subjects have been reported to be $552 \pm 36$ and $555 \pm 35 \mu \mathrm{m}$, respectively, when measured by ultrasound pachymetry. ${ }^{32-33}$ Cho and $\mathrm{Lam}^{34}$ reported thicker readings for CCT in Hong Kong Chinese, with $575 \pm 31$ for males and $574 \pm 33$ in females. However, in a Mongolian population $(1,129$ subjects), measured CCT was only $495 \pm 32 \mu \mathrm{m}$ for right eyes and $514 \pm 32$ 
for left eyes. ${ }^{35}$ In a study of young New Zealanders, Herse and Weiping ${ }^{36}$ did not find significant differences between five cultural groups of children. Further multiple, interracial comparisons are needed in the same study using the same equipment, examiners, and conditions to draw stronger conclusions of ethnical differences in CCT.

Matsuda and associates ${ }^{37}$ compared Asian and white horizontal visible iris diameter and found a statistically significant racial difference. If corneal diameter is on average smaller in Asians, rate of corneal flattening may be greater in Asian eyes. Differences in corneal curvature and diameter are of interest to those prescribing contact lens and the manufacture of cosmetic lens for certain markets.

In a large study (1,235 patients $40-75$ years old), Snellingen and associates $^{38}$ studied interethnic differences of the corneal endothelium that analyzes the differences of corneal endothelial cell density, cell size variability, and cell hexagonality between different ethnic groups. Three groups were studied, those of Nepali, Bangladeshi, and South Indian descent. All mean measurements in Table 4 were significantly significant $(p<.0001)$.

In a smaller, earlier study (156 patients), Matsuda and coworkers ${ }^{39}$ compared corneal endothelial density between an American population and a Japanese population. They found no significant difference between variations in cell area and cell shape between the two populations, but the Japanese group had a higher endothelial cell density (in all age groups $10->70$ years old). They suggested that this might account for a lower incidence of aphakic bullous keratopathy in Japanese than in Americans. Snellingen and associates ${ }^{38}$ proposed that there is a need for further interethnic studies of corneal endothelium to determine whether certain ethnic groups are more prone to surgical trauma.

\section{- Anterior Chamber}

Racial difference in angle configuration may account for racial differences in the incidence of primary angle-closure glaucoma (PACG). Understanding the anatomical variations is of great value especially in screen-

Table 4. Interethnic Differences in Corneal Endothelium

\begin{tabular}{lccc}
\hline Ethnic Group & $\begin{array}{c}\text { Cell } \\
\text { Density }\left(\mathrm{mm}^{2}\right)\end{array}$ & $\begin{array}{c}\text { Cell Size } \\
\text { Variability }(\%)\end{array}$ & $\begin{array}{c}\text { Cell } \\
\text { Hexagonality }(\%)\end{array}$ \\
\hline Nepali & $2,634(386)$ & $39.3(7.4)$ & $34.4(7.0)$ \\
Bangladeshi & $2,782(342)$ & $33.2(5.7)$ & $37.8(5.8$ \\
South Indian & $2,714(360)$ & $41.3(6.4)$ & $45.2(8.9)$ \\
\hline
\end{tabular}

Note: All measurements represent the mean standard deviation. Source: Snellingen et al. ${ }^{38}$ 
ing patients for PACG. Compared to whites, who have an incidence of PACG of 0.05 to $0.1 \%,{ }^{40,41}$ Inuits who have a higher prevalence of angle closure glaucoma $(1.1-11.4 \%)^{42,43}$ were found to have shallower angleanterior chambers than did other races. ${ }^{20,44-46}$ It has been reported that Far East Asians have an incidence of PACG around 1\%, which is a 10times-higher incidence of PACG than that of whites. ${ }^{19,47}$ It is possible that PACG affects 30 million Asian people worldwide. ${ }^{48} \mathrm{Oh}$ and coworkers ${ }^{47}$ performed detailed gonioscopy of the anterior chambers of AfricanAmericans, Caucasians, and Far East Asians. They did not find statistical difference between the actual numerical measurements of the angles of these three groups (mean $\pm \mathrm{SD}$ ) angle width in degrees: whites, $32.5 \pm 5.5$; African-Americans, $31.8 \pm 5.5$; Asians, $33.4 \pm 6.8$. However, they did report a more anterior insertion of the iris root in Asian subjects than in the other groups. The insertion was found to be the most posterior in those in the white group. This difference in angle configuration was postulated to be a reason behind the predisposition of Asians to PACG even though Asians tend to be more myopic (and therefore are expected to have deeper anterior chamber angles).

Congdon and coinvestigators ${ }^{19}$ also measured anterior chamber differences in Chinese, white, and black populations to explore why PACG is more prevalent in Chinese. Their measurements included anterior chamber depth, axial length, radius of corneal curvature, and refractive error. The only parameter that differed significantly between Chinese and other groups and might explain the increased risk of PACG among Chinese was the smaller radius of corneal curvature as compared to whites and blacks. A smaller corneal radius of curvature implies a smaller anterior chamber volume and more crowded anterior chamber. Congdon and coworkers later postulated that older Chinese may develop a "creeping angle closure" that could account for a increased incidence of PACG.

In concordance with other studies, ${ }^{44-46}$ Wojciechowski and associate $^{20}$ recently found Inuit subjects to have shallower peripheral and central anterior chambers than Chinese, blacks, and whites $(p<.01)$. Of great interest is that the age-adjusted measurements of visible angle structures were significantly smaller for the Inuit subjects and showed a significantly more rapid decline in angle (along with anterior chamber depth) with age than whites and blacks. Chinese subjects also had a more rapid decline in angle structure than did whites and blacks, but the values did not differ significantly from those of the Inuits. In addition, Inuits had larger ageadjusted lens thickness than all three other groups. Therefore, Inuits may have the higher incidence of PACG from having shallower and narrower angles, possibly affected by lens size. As stressed by Wojciechowski and associates, ${ }^{20}$ long-term prospective studies are needed to control for confounding factors, such as earlier cataract formation and lens swelling in some groups that may be more prevalent with different diets and ultraviolet light exposure levels. There may be a cohort effect in Inuit and 
Chinese, with younger subjects having deep angles (being more myopic) induced from educational-near work stresses that may cause it to appear that angles are narrowing with age in a population.

\section{- Iris}

Blue irides, more commonly found in white races, appear blue owing to the lack of pigment on the anterior surface of the iris.$^{50}$ As a result, light passes through a relatively clear stroma and creates a scatter of light as does the sky, making the medium appear blue. ${ }^{50}$ Duke-Elder and Wybar ${ }^{50}$ reported that if the stroma becomes more dense in blue iris, the iris then appears more gray. Iris vessels also are more visible in lighter-colored irides, owing to the lack of pigment, and this may be important for those inexperienced who are looking for iris or angle neovascularization. Also of clinical value, in white patients, age-related macular degeneration is significantly more prevalent in individuals with blue or hazel irides than in those with light-colored irides. ${ }^{51}$

\section{- Lens}

There is little discussion of racial anatomical lens differences in the literature. ${ }^{20,52}$ A larger, thicker lens may make one prone to angle closure. Some ethnic groups are more prone to angle closure, but there is no convincing evidence in the literature to support that there is a racial difference in lens size to account for an ethnic predisposition. One study found that in normal patients without a history of acute angle closure, black patients had a significantly thinner lens $(0.4 \mathrm{~mm}$ thinner; $p<.0005)$ than that of Danish patients. ${ }^{52}$ A smaller lens may explain a relatively lower incidence of acute closure attacks in some black populations. ${ }^{52,53}$ Wojciechowski and associates ${ }^{20}$ found that an Inuit population (that has a higher incidence of anterior chamber angle closure) had significantly thicker lenses than did Chinese, black, and white populations. Owing to the presence of many confounding factors and only cross-sectional analysis, no study has yet shown a true racial anatomical difference in lens size or shape.

\section{- Optic Nerve-Disc}

Ethnic differences in disc size and other parameters have been reported. ${ }^{5-58}$ Mansour $^{57}$ reported a statistically significant smaller optic disc in whites and Hispanics than in Southeast Asians, Far East Asians, and blacks. Blacks on average had a disc area $26 \%$ larger $\left(3.33 \mathrm{~mm}^{2}\right.$ vs. 2.6 
$\mathrm{mm}^{2}$ ) than whites. In a later study, Mansour ${ }^{58}$ examined the optic discs of children and reported that blacks had significantly larger vertical disc diameters (by $0.21 \mathrm{~mm}$ or $11 \%$ larger; $p<.0001$ ) and disc areas (by 0.42 $\mathrm{mm}^{2}$ or $16 \%$ larger; $\left.p<.002\right)$. The horizontal disc diameters were moderately large (by $0.08 \mathrm{~mm}$ or $5 \%$ larger), but the difference barely missed making statistical significance $(p<.07)$. Chi and coworkers ${ }^{59}$ used an optic disc analyzer to compare the optic discs of 30 black and 31 white subjects and also found that blacks had significantly larger disc areas. Therefore, race-based variation of optic disc size appears to be significant. Also, a smaller optic disc in whites may have some bearing on their higher prevalence of nonarteritic ischemic optic neuropathy and optic disc drusen. ${ }^{60,61}$

Mansour $^{58}$ also reported very similar neuroretinal rim areas between black and white children. There were no differences between these races. Chi and associates ${ }^{59}$ also found similar neural rim areas in normal adult blacks and whites, even though $\mathrm{C} / \mathrm{D}$ ratios and disc areas differed. Racial variation must be taken into consideration because there may be some people with large disc and thinner neural rims that will be given false diagnoses or more often referred for glaucoma. ${ }^{62}$

From evaluation of stereoscopic photographs taken from 100 black and 100 white patients, Beck and associates ${ }^{63}$ reported the average C/D ratio in blacks as 0.35 and in whites as $0.24(p<.0001)$. They also reported that $40 \%$ percent of the optic discs of blacks and $14 \%$ of the optic discs of whites had a C/D ratio greater than or equal to 0.4. Later studies have confirmed this racial difference in $\mathrm{C} / \mathrm{D}$ ratios. ${ }^{58,59,64} \mathrm{Chi}$ and coworkers ${ }^{59}$ found larger cup-to-disc ratios in blacks, being 0.21 larger than in whites $(p<.0001)$. Mansour ${ }^{58}$ also found the $\mathrm{C} / \mathrm{D}$ ratios were significantly larger in blacks than in whites.

A histological and photographic study by Dandona and coworkers ${ }^{54}$ sought to determine whether less connective tissue support in the lamina cribosa is present in black subjects as compared to white subjects. The black subjects were found to have a larger total lamina cribosa area, indicating a larger optic nerve head. However, Dandona and coinvestigators ${ }^{54}$ reported that the connective tissue proportion and pore size were almost identical in black and white subjects. The mean value for the connective tissue proportion in the lamina cribosa was $56 \%$ of total lamina cribosa area for blacks and $55.2 \%$ for whites.

\section{Retina}

On fundus examination, the retinal background of those with lighter skin generally is more of a reddish-orange color compared to a darkerorange color in those with darker skin. In an optical transmission and fluorescence study comparing the eyes of black and white subjects, black 
subjects had a significantly greater amount of choroidal melanin, although blacks and whites have a similar amount of melanin in the retinal pigment epithelium (RPE). ${ }^{65}$ White subjects have been shown to have significantly higher levels of lipofuscin in the RPE. ${ }^{65}$

A racial difference in the peripapillary nerve fiber layer (NFL) has been demonstrated in one study using scanning laser polarimetry to study normal patients. ${ }^{66}$ Adjusting for age, in more than one-half the age groups, they found that whites had a significantly thicker nerve fiber layer on average than did Afro-Caribbean subjects. The retinal NFL thickness in whites ranged from 60.3 to $105.3 \mu \mathrm{m}$. The retinal NFL in Afro-Caribbeans ranged from 71.8 to 94.9 . This difference in NFL thickness may have clinical relevance with respect to the clinical course of glaucoma, but further studies are needed to confirm such findings.

\section{Summary}

This chapter summarized racial and ethnic differences in ocular anatomy involving the eye and the orbit. There are distinct racial and ethnic anatomical differences in the ocular structures. By recognizing and appreciating such differences and incorporating them into clinical practice, physicians will be better able to differentiate between normal and abnormal and to manage and diagnose various ocular diseases.

This study was supported in part by the Research to Prevent Blindness, Inc, New York, NY and by Core Grant EY01792, National Institutes of Health, Bethesda, MD.

\section{- References}

1. Flowers RS. The art of eyelid and orbital aesthetics: multiracial surgical considerations. Clin Plast Surg 1987;14:703-721

2. Park JI. Orbicularis-levator fixation in double-eyelid operation. Arch Facial Plast Surg 1999;1:90-95

3. Rubenzik R. Surgical revision of the oriental lid. Ann Ophthalmol 1977;9:1189-1192

4. Cheng J, Xu FZ. Anatomic microstructure of the upper eyelid in the Oriental double eyelid. Plast Reconstr Surg 2001;107:1665-1668

5. Doxanas MT, Anderson RL. Oriental eyelids—an anatomic study. Arch Ophthalmol 1984;102:1232-1235

6. Jeong A, Lemke BN, Dortzbach RK, et al. The Asian upper eyelid-an anatomical study with comparison to the Caucasian eyelid. Arch Ophthalmol 1999;117:907-912

7. Carter SR, et al. The Asian lower eyelid: a comparative anatomic study using highresolution magnetic resonance imaging. Ophthal Plast Reconstr Surg 1998;14:227-234

8. Farkas LG, Cheung G. Orbital measurements in the presence of epicanthi in healthy North American Caucasians. Ophthalmologica (Basel) 1979;179:309-315

9. Stromland K, Pinazo-Duran MD. Ophthalmic involvement in the fetal alcohol syndrome: clinical and animal model studies. Alcohol Alcohol 2002;37:2-8 
10. Hanada AL, Nunes de Souza E Jr, Moribe I, Cruz AAV. Comparison of palpebral fissure obliquity in three different racial groups. Ophthal Plast Reconstr Surg 2001;17:423-426

11. Migliori ME, Gladstone GJ. Determination of the normal range of exophthalmometric values for black and white adults. Am J Ophthalmol 1984;98:438-442

12. Dunsky IL. Normative data for Hertel's exophthalmometry in a normal adult black population. Optom Vis Sci 1992;69:562-564

13. Barretto RL, Mathog RH. Orbital measurement in black and white populations. Laryngoscope 1999;109:1051-1054

14. Bolanos Gil de Montes F, Perez Resinas FM, Rodriguez Garcia M, Gonzalez Ortiz M. Exophthalmometry in Mexican adults. Rev Invest Clin 1999;51:341-343

15. Pryor HB. Objective measurement of interpupillary distance. Pediatrics 44;6:973-977

16. Pivnick EK, Rivas ML, Tolley EA, et al. Interpupillary distance in a normal black population. Clin Genet 1999;55:182-191

17. Osuobeni EP, Al-Gharni SS. Ocular and facial anthropometry of young adult males of Arab origin. Optom Vis Sci 1994;71:33-37

18. Lam CSY, Goh WSH. The incidence of refractive errors among school children in Hong Kong and its relationship with the optical components. Clin Exp Optom 74:97-103

19. Congdon NG, Youlin Q, Quigley H, et al. Biometry and primary angle-closure glaucoma among Chinese, white and black populations. Ophthalmology 1997;104:1489-1495

20. Wojciechowski R, Congdon N, Anninger W, Broman AT. Age, gender, biometry, refractive error, and the anterior chamber angle among Alaskan Eskimos. Ophthalmology 2003;110:365-375

21. Sperduto RD, Seigel D, Roberts J, Rowland M. Prevalence of myopia in the United States. Arch Ophthalmol 1983;101:405-407

22. Au Eong KG, Tay TH, Lim MK. Race, culture and myopia in 110,236 young Singaporean males. Singapore Med J 1993;34:29-32

23. Wu HM, Seet B, Yap EPH, et al. Does education explain ethnic differences in myopia prevalence? A population-based study of young adult males in Singapore. Optom Vis Sci 2001;78:234-239

24. Zadnik K, Mutti DO, Friedman NE, et al. Initial cross-sectional results from the Orinda Longitudinal Study of Myopia. Optom Vis Sci 70:750-758

25. Wang Q, Klein BEK, Klein R, et al. Refractive status in the Beaver Dam Eye Study. Invest Ophthalmol Vis Sci 35:4344-4347

26. Rassmussen OD. Incidence of myopia in China. Br J Ophthalmol 1936;20:350-360

27. Henkind P, Friedman AH. External ocular pigmentation. Int Ophthalmol Clin 1971(Fall);11:87-111

28. Norn M. Pigmented spots related to scleral emissaries in Eskimos, Mongols, and Caucasians. Acta Ophthal 1985;63:236-241

29. Yanoff M. Pigment spots of the Sclera. Arch Ophthalmol 81:151-154

30. Brandt JD, Beiser JA, Kass MA, et al. Central corneal thickness in the Ocular Hypertension Treatment Study. Ophthalmology 2001;108:1779-1788

31. La Rosa FA, Gross RL, Orengo-Nania S. Central corneal thickness of Caucasians and African Americans in glaucomatous and nonglaucomatous populations. Arch Ophthalmol 2001;119:23-27

32. Wong ACM, Wong CC, Yuen NSY, et al. Correlational study of central corneal thickness measurements on Hong Kong Chinese using optical coherence tomography, Orbscan and ultrasound pachymetry. Eye 2002;16:715-721

33. Wu LL, Suzuki YM, Ideta R, et al. Central corneal thickness of normal tension glaucoma patients in Japan. Jpn K Ophthalmol 2000;44:643-647

34. Cho P, Lam C. Factors affecting the central corneal thickness of Hong Kong-Chinese. Curr Eye Res 1999;5:368-374

35. Foster PJ, Baasanhu J, Alsbirk PH, et al. Central corneal thickness and intraocular pressure in a Mongolian population. Ophthalmology 1998;105:969-973 
36. Herse P, Weiping Y. Variation of corneal thickness with age in young New Zealanders. Acta Ophthalmol 1993;71:360-364

37. Matsuada LM, Woldorff CL, Kame RT, Hayashida JK. Clinical comparison of corneal diameter and curvature in Asian eyes with those of Caucasian eyes. Optom Vis Sci 1992;69:51-54

38. Snellingen T, Gullapalli NR, Shrestha JK, et al. Quantitative and morphological characteristics of the human corneal epithelium in relation to age, gender, and ethnicity in cataract populations of South Asia. Cornea 2001;20:55-58

39. Matsuda M, Yee RW, Edelhauser HF. Comparison of the corneal endothelium in an American and Japanese population. Arch Ophthalmol 1985;103:68-70

40. Hollows FC, Graham PA. Intraocular pressure, glaucoma, and glaucoma suspects in a defined population. Br J Ophthalmol 1966;50:570

41. Bengtsson B. The prevalence of glaucoma. Br J Ophthalmol 1981;65:46-49

42. Drance SM. Angle closure glaucoma among Canadian Eskimos. Can J Ophthalmol 1973;8:252-254

43. Arkell SM, Lightman DA, Sommer A. The prevalence of glaucoma among Eskimos of Northwest Alaska. Arch Ophthalmol 1987;105:482-485

44. Drance SM, Morgan RW, Bryett J. Anterior chamber depth and gonioscopic findings among the Eskimos and Indians in the Canadian Arctic. Can J Ophthalmol 1973;8: 255-259

45. Alsbirk PH, Forsius H. Anterior chamber depth in Eskimos and Greenland, Canada (Igloolik), and Alaska (Wainwright). A preliminary report. Can J Ophthalmol 1973:8: 265-269

46. Alsbirk PH. Primary angle closure glaucoma. Oculometry, epidemiology, and genetics in a high risk population (Greenland Eskimos). Acta Ophthalmol Suppl 1976;127:5-31

47. Oh YG, Minelli S, Spaeth GL. The anterior chamber angle is different in different racial groups: a gonioscopic study. Eye 1994;8:104-108

48. Quigley HA. Number of people with glaucoma worldwide. Br J Ophthalmol 1996;80: 389-393

49. Congdon NG, Foster PJ, Wamsley S, et al. Biometric gonioscopy and the effects of age, race, and sex on the anterior chamber angle. Br J Ophthalmol 2002;86:18-22

50. Duke-Elder S, Wybar KC. The anatomy of the visual system. In: System of ophthalmology. St Louis: Mosby, 1961:167-171

51. Frank RN, Puklin JE, Stock C, Canter LA. Race, iris color, and age-related macular degeneration. Trans Am Ophthalmol Soc 2000;98:109-115

52. Clemmesen V, Luntz MH. Lens thickness and angle-closure glaucoma. A comparative oculometric study in South African Negroes and Danes. Acta Ophthalmol (Copenh) 1976;54:193-197

53. Luntz MH. Primary angle-closure glaucoma in urbanized South African caucasoid and negroid communities. Br J Ophthalmol 1973;57:444-456

54. Dandona L, Quigley HA, Brown AE, et al. Quantitative regional structure of the normal human lamina cribosa. A racial comparison. Arch Ophthalmol 108:393-398

55. Sommer A, Katz J, Quigley HA, et al. Clinically detectable nerve fiber atrophy precedes the onset of glaucomatous field loss. Arch Ophthalmol 1991;109:77-83

56. Gordon MO, Beiser JA, Brant JD, et al. The Ocular Hypertension Treatment Study: baseline factors that predict the onset of primary open-angle glaucoma. Arch Ophthalmol 2002;120:714-720

57. Mansour AM. Racial variation of the optic disc size. Ophthalmic Res 1991;23:67-72

58. Mansour AM. Racial variation of optic disc parameters in children. Ophthalmic Surg 1992;23(7):469-471

59. Chi T, Ritch R, Stickler D, et al. Racial differences in optic nerve head parameters. Arch Ophthalmol 1989;1076:836-839

60. Jonas JB, Gusek GC, Naumann GOH. Anterior ischemic optic neuropathy: nonarteritic 
form in small, and giant cell arteritis in normal sized optic discs. Int Ophthalmol 1988;12:119-125

61. Jonas JB, Gusek GC, Guggenmoos-Holzmann I, et al. Optic nerve head drusen associated with abnormally small optic discs. Int Ophthalmol 1987;11:79-82

62. Levi L, Schwartz B. Glaucoma screening in the health care setting. Surv Ophthalmol 1938;28:164-174

63. Beck RW, Messner DK, Musch DC, et al. Is there a racial difference in physiologic cup size? Ophthalmology 1985;92:873-876

64. Varma R, Tielsch JM, Quigley HA. Race-, age-, gender-, and refractive error-related differences in normal optic disc. Arch Ophthalmol 1994;112:1068-1076

65. Weiter JJ, Delori FC, Wing GL, et al. Retinal pigment epithelial lipofuscin and melanin and choroidal melanin in human eyes. Invest Ophthalmol Vis Sci 1986;27:145-152

66. Poinoosawmy D, Fontana L, Wu JX, et al. Variation of nerve fiber layer thickness measurements with age and ethnicity by scanning laser polimetry. Br J Ophthalmol 1997;81:350-354 